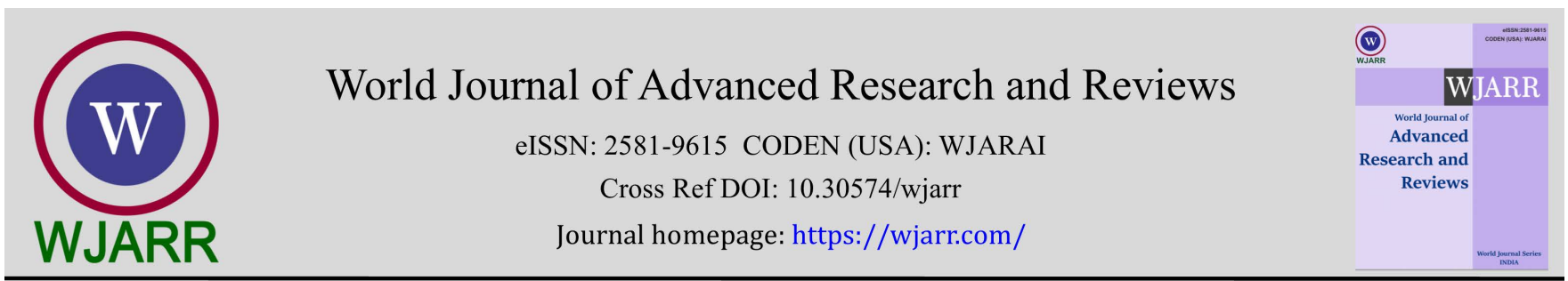

(RESEARCH ARTiClE)

\title{
Effects of methanolic leaf extract of Kigelia africana on hemodynamic parameters and redox status of normotensive wistar rats
}

\author{
Oyelade Waheed Abimbola 1, ${ }^{*}$, Olaleye MT 1, Oyebode ${ }^{1}$, Joseph Ademola ${ }^{1}$ and Fajilade Temilade Olawande ${ }^{2}$ \\ ${ }^{1}$ Department of Science Technology, Federal Polytechnic, Ado-Ekiti, Nigeria. \\ 2 Department of Biochemistry, Federal University of Technology, Nigeria.
}

World Journal of Advanced Research and Reviews, 2021, 11(02), 010-019

Publication history: Received on 19 February 2021; revised on 10 April 2021; accepted on 15 April 2021

Article DOI: https://doi.org/10.30574/wjarr.2021.11.2.0116

\begin{abstract}
Kigelia Africana has a rich history of ethnobotanical usage in the treatment of a wide range of illnesses andcomplications like hypertension, cancer and microbial infections in south western Nigeria. The present work sought to investigate the effects of methanolic leaf extract of Kigelia Africana on the blood pressure and biochemical indices of normotensive albino rats. Twenty five male albino Wistar rats, weighing between 180-200g, and divided into five groups (I-V) of five animals each were used for the experiment. GroupsII - V were administered 1mg/kg b.w ramipril, 25-, 50- and $100 \mathrm{mg} / \mathrm{kg}$ b.wKigelia Africana respectively by oral gavage for 14 consecutive days. Group I received vehicle $(1 \mathrm{mg} / \mathrm{kg}$ distilled water) only throughout the duration of the experiment and served as control. Twenty-four hours after the last administration, the blood pressure was determined before sacrificing the animals following anesthesia. The activities of serum biomarkers (aspartate aminotransferase AST, total protein TP, alanine aminotransferase ALT, alkaline phosphatase ALP), serum lipid profile; (cholesterol TC, low/very low density lipoprotein LDL-c/VLDL-c, high density lipoprotein HDL and triglyceride TG) and cardiac antioxidant indices (catalase CAT, superoxide dismutase SOD and glutathione GSH) were determined. Administration of ramipril (1mg/kg b.w) and all dosages of Kigelia africana (25, 50 and $100 \mathrm{mg} / \mathrm{kg}$ b.w) caused significant $(\mathrm{P}<0.05)$ decrease in the blood pressure of the animals when compared to the control. The values obtained further showed that ramipril and the extract (at all dosages) caused significant reduction in TC, TG, LDL-c and VLDL-c and coronary risk index, CRI while there was significant increase in the level of HDL when compared to the control.

All dosages of Kigelia africana extract resulted in significant $(\mathrm{P}<0.05)$ decrease in serum activities of AST, ALT and ALP when compared with the control. The significant $(\mathrm{P}<0.05)$ increases in cardiac catalase activity and GSH concentration recorded in rats treated with Kigelia africana $(25,50$ and $100 \mathrm{mg} / \mathrm{kg}$ b.w.) were comparable with those administered the reference drug, ramipril (1 mg/kg). Cardiac SOD activity was however decreased in rats administered extract (25, 50 or $100 \mathrm{mg} / \mathrm{kg} \mathrm{b.wt)}$ and ramipril (1mg/kg bw). The results suggest the hypolipidemic, hypotensive and antioxidant properties and of methanolic extract of Kigelia africana leaf and lend support to the ethnobotanical usage of the leaf in the treatment of hypertension.
\end{abstract}

Keywords: Kigelia Africana; Hemodynamic Parameters; Redox Status; Normotensive Albino Rats

\section{Introduction}

Medicinal plants have been used for centuries before the advent of orthodox medicine. Leaves, flowers, stems, roots, seeds, fruit, and bark can all be constituents of herbal medicines. The medicinal values of these plants lie in their phytochemicals, which produce definite physiological actions on the human body [1]. The phytochemicals include alkaloids, saponins, tannins, phlobatannins, anthraquinones, glycosides, flavonoids, steroids, terpenoids e.t.c. The presence of these phytochemicals is suggestive of potent bioactivity. The antioxidant activity of phenolics is due to their

*Corresponding author: Oyelade Waheed Abimbola; E-mail: oyebiochemist@yahoo.com

Biochemistry Unit, Department Of Science Technology, The Federal Polytechnic, Ado Ekiti.

Copyright (c) 2021 Author(s) retain the copyright of this article. This article is published under the terms of the Creative Commons Attribution Liscense 4.0. 
redox properties which allow them to act as reducing agents, metal chelators and free radical scavengers [2];[3]. It has also been recognized that flavonoids show antioxidant activity and their effects on human nutrition and health are considerable [4]. (Farombi et al., 1998). Antioxidants are the antidotes to the voracious electron appetite of free radicals and reactive oxygen species. Plant phytochemicals may be effective in combating or preventing disease due to their antioxidant effect [5],[4].

Cardiovascular diseases account for 12 million deaths, annually worldwide and are known to be number one 'killer disease'. Hypertension (HTN) or high blood pressure, sometimes called arterial hypertension, is a chronic medical condition in which the blood pressure in the arteries is elevated. It is the common chronic illness among the world faces [6].

Hypertension is the most common cardiovascular diseases and constitutes a major risk factor for several cardiovascular pathologies including atherosclerosis, coronary artery diseases, and myocardium infarct, heart failure, renal insufficiency, stroke and dissecting aneurysm of aorta [6].

An elevated arterial pressure is an important public health issue in developed countries. Although it is common, asymptomatic and readily detectable but it can often lead to lethal complication, if left untreated. Because of high incidence and morbidity, various drugs and regimes have been advocated for the control of hypertension. Many new drugs have been introduced which may demonstrate better efficacy but possess side effects. Recently, attention has been focused towards herbal and mineral preparations which are traditionally used as potential therapeutic agents in the prevention and management of cardiovascular diseases [6].

Kigeliaafricana (Lam.) Benth is commonly known as sausage tree in English or Pandoro among the Yoruba speaking people of south-western Nigeria. It is used in folk medicine in the treatment of many diseases. The leaf and bark extracts are commonly employed for the treatment of several ailments like pneumonia, epilepsy, rheumatism, and hypertension. The root extracts are used for making dyes while the fruits are also eaten for nutritional supplements [7]. Several works have been done on the Kigelia africana leaf which includes: analgesic effect, anti-inflammatory effect, antibacterial effect, central nervous stimulating effect and smooth muscle relaxing activities effects. However, the hypotensive effects of Kigelia africana is yet to be carried out by someone else.

Hence the present work was undertaken to investigate the hypotensive effect and toxicity of methanolic leaf extract of Kigelia africana.

\section{Material and methods}

\subsection{Plant Materials}

Fresh leaves of Kigelia Africana were obtained from Iyana Emirin, Ado Ekiti, Ekiti State, Nigeria in April 2013. Identification was carried out at Forestry Research Institute of Nigeria, Ibadan, Oyo state Nigeria.

\subsection{Reagents and Chemicals}

All Chemicals and Reagents used were of Analytical grades.

\subsubsection{Preparation of Aqueous - Methanolic Extract of Kigelia africana leaf}

Kigelia africana leaves were air-dried for 28 days at room temperature. The air-dried leaves were ground to fine powder using a blender. $500 \mathrm{~g}$ of the powdered leaves was soaked in $1200 \mathrm{ml}$ of $80 \%$ methanol for 74 hours, filtered, concentrated to a small volume to remove the entire methanol using rotary evaporator and freeze-dried to obtain the dried extract. The extract was kept in a closed container and kept inside the fridge at $4^{0} \mathrm{C}$ for further studies.

\subsubsection{Acute Oral Toxicity Study}

Acute oral toxicity study of methanolic extract of Kigelia africana was carried out in wistar rats. Extract, at different doses, was administered and the animals were observed for behavioral change, toxicity and mortality up to $48 \mathrm{~h}$.

\subsubsection{Experimental Design}

Rats were divided into five groups (I-V) of five animals each and treated as follows. 
Group I: Animals in this group received distilled water only throughout the duration of the experiment (14 days) and served as the control.

Group II: Animals received ramipril (1 mg/kg b.w.) by gavage once daily for 14 consecutive days.

Group III: Animals were orally administered Kigelia africana extract ( $25 \mathrm{mg} / \mathrm{kg} \mathrm{b.w}$ ) once daily for 14 consecutive days. Group IV: Animals were orally administered Kigelia africana extract (50 mg/kg b.w) once daily for 14 consecutive days. Group V: Animals were orally administered Kigelia africana extract (100 mg/kg b.w) once daily for 14 consecutive days.

The dosages administered were obtained from previous studies done on the antimicrobial activities effect of the extract.

\subsubsection{Evaluation of Rat Blood Pressure}

The blood pressure of rats was determined as described by [8]. Upon anesthesia, the animals were anaesthetized with an intraperitoneal injection of $25 \%$ urethane and $1 \%$ chloralose $(5 \mathrm{ml} / \mathrm{kg} \mathrm{b} . \mathrm{w})$. The trachea was exposed and cannulated to facilitate easy respiration. The left femoral vein was cannulated to facilitate the intravenous injection of the plant extracts. The right carotid artery was also cannulated and connected to a pressure transducer (Statham P23 XL) coupled with a Grass Polygraph (Model 7D, Quincy, MA, USA). Heparin (500 IU/kg) was injected to prevent intravascular blood clotting. The speed of the Grass Polygraph was $10 \mathrm{~mm} / \mathrm{sec}$. The blood pressure was evaluated as recorded in form of tracing by the polygraph after a 10 -min stabilization period. The rats' temperature was maintained at $37^{\circ} \mathrm{C}$ with a heating pad throughout the experiment. On the tracing, the values from the baseline to the lowest border of the tracing represent the diastolic pressure while from the baseline to the upper border represent the systolic pressure. Each centimeter $(\mathrm{cm})$ change on the tracing paper corresponds to $20 \mathrm{mmHg}$ pressure change in the grass polygraph. The mean arterial blood pressure (MAPB) was calculated as shown: MAPB= DP +1/3 (SP-DP); Where DP= Diastolic pressure and $\mathrm{SP}=$ Systolic pressure. Heart rate (beats/min) corresponds to the number of strokes within a distance of $600 \mathrm{~mm}$ $(60 \mathrm{~cm})$ on the polygraph recordings.

\subsubsection{Preparation of Serum}

The carotid artery cannulated with the catheter was occluded, to prevent loss of blood from the opening. The rats were dissected and blood collected through cardiac puncture into clean centrifuge tubes and allowed to stand for $1 \mathrm{~h}$. Serum was prepared by centrifugation at $3000 \mathrm{~g}$ for $15 \mathrm{~min}$ at $25^{\circ} \mathrm{C}$. The clear supernatant was collected and used for the estimation of serum biochemical parameters.

\subsubsection{Preparation of Homogenates}

The hearts were excised using scissors and forceps. They were trimmed of fatty tissue, washed in ice cold $1.15 \%$ potassium chloride solution, blotted with filter paper and weighed. They were then chopped into bits and homogenized in ten volumes of the homogenizing phosphate buffer $(\mathrm{pH} 7.4)$ using a Teflon homogenizer. The resulting homogenates were centrifuged at $6000 \mathrm{~g}$ at $4^{\circ} \mathrm{C}$ for 30 mins. The supernatant obtained was collected and stored under $4^{\circ} \mathrm{C}$ and then used for biochemical analyses.

\subsection{Serum Biomarkers (Enzymes)}

\subsubsection{Determination of Serum Creatine Kinase ( $C k-M b)$ Activity}

The modified reagent, creatinekinase- $\mathrm{N}$-acetyl-cystein (CK-NAC) contains a polyclonal antibody which is specific to the CK-M monomer.It completely inhibits CK-MM activity and one half of CK-MB activity [9]. (Mattenheimer, 1981). Only the activity of the non-inhibited B monomer subunit, representing half of the CK-MB activity is measured. The method assumes that CK-BB activity in the specimen is essentially zero. The method was described by [10]. Stein (1981).

\subsubsection{Assay of Aspartate Aminotransferase (AST) Activity}

AST activity was determined following the principle described by [11].

\subsubsection{Assay of Alanine Aminotransferase (ALT) Activity}

The principle described by [11], was followed in the assay of ALT using commercially available assay kit (Randoxlaboratories, UK) according to the instructions of the manufacturer.

\subsubsection{Assay of Akaline Phosphatase (ALP) Activity}

Assay of serum ALP was based on the method of [12], using commercial assay kits (Randox laboratories, UK) according to the instructions of the manufacturer. 


\subsection{Serum Lipid Profile Analysis}

\subsubsection{Estimation of Total Cholesterol Level}

Total cholesterol level was determined based on the method of [13], using commercially available kits (Randox laboratories, UK).

\subsubsection{Evaluation of Concentration of Triglyceride}

Triglyceride's level was determined based on the method of [14], using commercially available kits (Randox laboratories, UK).

\subsubsection{High Density Lipoprotein (HDL-c)-Cholesterol Assay}

The method of [15], was adopted in estimation of the concentration of the HDL- cholesterol in the serum.

\subsubsection{Low Density Lipoprotein (LDL) - Cholesterol Determination}

The concentration of low-density lipoprotein in the serum was calculated using the formula of [16], as given below:

$$
\text { LDL cholesterol }=\text { Total cholesterol }-\frac{\text { Triglycerides }}{5}-\text { HDL }- \text { cholesterol }
$$

\subsubsection{Very Low-Density Lipoprotein (VLDL) - Cholesterol Determination}

The concentration of very low-density lipoprotein in the serum was calculated using the formula of [16], al. as given below:

$$
\text { VLDL cholesterol }=\frac{\text { Triglycerides }}{5}
$$

\subsubsection{Coronary Risk Index Estimation}

The coronary risk index was calculated using the formula of [16], as given below:

$$
\mathrm{CRI}=\frac{\text { Cholesterol }}{\text { High Density Lipoprotein }}
$$

\subsection{Antioxidant assay}

\subsubsection{Determination of Catalase Activity}

This experiment was carried out using the method described by [17].

\subsubsection{Determination of Superoxide Dismutase (SOD) Activity}

The level of SOD activity was determined by the method of [18].

\subsubsection{Determination of Reduced Glutathione (GSH) Level}

The method of [19], was followed in estimating the level of reduced glutathione (GSH).

\subsubsection{Determination of Total Protein (TP) in Serum}

The Biuret method described by [20], was employed in the determination of total protein in the serum using commercially available kits (Randox laboratories, UK).

\subsubsection{Statistical Analysis}

All values are expressed as mean \pm SD. Statistical evaluation was done using One Way Analysis of Variance (ANOVA) followed by Duncan's Multiple Range Test (DMRT) by using SPSS 11.09 for windows [21]. The significance level was set at $\mathrm{p}<0.05$. 


\section{Results and discussion}

\subsection{Effects of Kigelia africana Leaf Extract on Hemodynamic Parameters of Normotensive Animals}

The effects of Kigelia Africana leaf extract on hemodynamic parameters of normotensive albino rats is given in Table $\mathbf{1}$.

The result showed that there was significant $(\mathrm{P}<0.05)$ decrease in systolic blood pressure of rats administered all dosages of Kigelia africana leaf extract. The highest decrease ( $42.20 \pm 1.48 \mathrm{mmHg}$ ) in systolic pressure was obtained in rats treated with $50 \mathrm{mg} / \mathrm{kg}$ of the extract when compared with the control $(67.00 \pm 2.23 \mathrm{mmHg})$.

The diastolic blood pressure was also significantly $(\mathrm{P}<0.05)$ decreased in the extract treated groups. In a similar trend with the systolic blood pressure, rats administered $50 \mathrm{mg} / \mathrm{kg}$ concentration recorded the lowest diastolic pressure $(30.60 \pm 1.95 \mathrm{mmHg})$ as compared with the control $(41.20 \pm 1.30 \mathrm{mmHg})$.

The pulse pressure of the animals treated with Kigelia africana leaf extract also decreased in a dose-dependent manner, with the highest concentration of the extract $100 \mathrm{mg} / \mathrm{kg}$ showing the lowest pressure $(8.80 \pm 2.28 \mathrm{mmHg})$ as compared with the control $(25.80 \pm 1.09 \mathrm{mmHg})$.

Similarly, the mean arterial blood pressure of the animals treated with the extract also decreased with increasing concentration. Animals placed on $50 \mathrm{mg} / \mathrm{kg}$ dosage exhibited the lowest pressure $(34.47 \pm 1.63 \mathrm{mmHg})$ as compared with the control $(49.80 \pm 1.59 \mathrm{mmHg})$.

The heart rate of the animals treated with the Kigeli aafricana leaf extract also decreased with increasing concentration of the extract. The highest dosage of extract $(100 \mathrm{mg} / \mathrm{kg})$ produced the lowest heart rate $(316.80 \pm 5.50 \mathrm{beats} / \mathrm{min}) \mathrm{as}$ compared with the control (401.60 7.36 beats $/ \mathrm{min})$.

Table 1 Effects of Kigelia africanal eaf extract on hemodynamic parameters of normotensive animals

\begin{tabular}{|l|l|l|l|l|l|}
\hline Group & SBP (mmHg) & DBP (mmHg) & PP (mmHg) & MABP (mmHg) & HR (mmHg) \\
\hline Control & $67.00 \pm 2.23^{\mathrm{d}}$ & $41.20 \pm 1.30^{\mathrm{c}}$ & $25.80 \pm 1.09^{\mathrm{d}}$ & $49.80 \pm 1.59^{\mathrm{d}}$ & $401.60 \pm 7.36^{\mathrm{a}}$ \\
\hline Standard & $40.20 \pm 1.79^{\mathrm{a}}$ & $30.80 \pm 0.84^{\mathrm{a}}$ & $9.40 \mathrm{ab} \pm 2.30$ & $33.93 \pm 0.59^{\mathrm{a}}$ & $357.60 \pm 3.05^{\mathrm{ab}}$ \\
\hline KA $(20) 53.80 \pm 1.92^{\mathrm{c}}$ & $36.40 \pm 1.52^{\mathrm{b}}$ & $17.40 \pm 1.14^{\mathrm{c}}$ & $42.20 \pm 1.57^{\mathrm{c}}$ & $383.80 \pm 4.76^{\mathrm{ab}}$ \\
\hline KA $(50) 42.20 \pm 1.48^{\mathrm{ab}}$ & $30.60 \pm 1.95^{\mathrm{a}}$ & $11.60 \pm 1.67^{\mathrm{b}}$ & $34.47 \pm 1.63^{\mathrm{a}}$ & $324.00 \pm 4.10^{\mathrm{a}}$ \\
\hline KA $\left.(100)^{4}\right)$ & $43.80 \pm 2.28^{\mathrm{b}}$ & $35.00 \pm 3.74^{\mathrm{b}}$ & $8.80 \pm 2.28^{\mathrm{a}}$ & $37.93 \pm 3.15^{\mathrm{b}}$ & $316.80 \pm 5.50^{\mathrm{a}}$ \\
\hline
\end{tabular}

Values are expressed as mean \pm standard deviation $(\mathrm{n}=5)$. Values with the different superscript(s) in a column are significantly different $(\mathrm{P}<0.05)$. SBP - Systolic blood pressure; DBP - Diastolic blood pressure; PP - Pulse pressure; MABP- Mean arterial blood pressure; HR - Heart rate.

Table 2 Effects of Kigelia Africana leaf extract on the activities of serum biomarkers of normotensive rats

\begin{tabular}{|l|l|l|l|l|}
\hline Group & AST (U/I) & ALT (U/I) & ALP (mg/dl) & CK-Mb (UI/L) \\
\hline Control & $26.84 \pm 0.51^{\mathrm{c}}$ & $9.36 \pm 0.48^{\mathrm{d}}$ & $82.50 \pm 2.33^{\mathrm{d}}$ & $38.92 \pm 4.7^{\mathrm{d}}$ \\
\hline K.A $(25 \mathrm{mg} / \mathrm{kg})$ & $26.00 \pm 0.24^{\mathrm{b}}$ & $7.40 \pm 0.28^{\mathrm{a}}$ & $68.64 \pm 2.76^{\mathrm{b}}$ & $21.64 \pm 2.9^{\mathrm{c}}$ \\
\hline K.A $(50 \mathrm{mg} / \mathrm{kg})$ & $26.80 \pm 0.30^{\mathrm{c}}$ & $7.60 \pm 0.23^{\mathrm{a}}$ & $70.62 \pm 1.81^{\mathrm{b}}$ & $19.22 \pm 2.5^{\mathrm{bc}}$ \\
\hline K.A $(100 \mathrm{mg} / \mathrm{kg})$ & $26.11 \pm 0.27^{\mathrm{c}}$ & $7.87 \pm 0.16^{\mathrm{b}}$ & $74.25 \pm 1.81^{\mathrm{c}}$ & $17.33 \pm 1.6^{\mathrm{ab}}$ \\
\hline Ram. $(\mathrm{I} \mathrm{mg} / \mathrm{kg})$ & $25.40 \pm 0.43^{\mathrm{a}}$ & $8.48 \pm 0.46^{\mathrm{c}}$ & $68.64 \pm 2.76^{\mathrm{a}}$ & $13.72 \pm 2.3^{\mathrm{a}}$ \\
\hline
\end{tabular}

Values are expressed as mean \pm standard deviation $(\mathrm{n}=5)$. Values with different superscript(s) in a row are significantly different $(\mathrm{P}<0.05) . \mathrm{K}$. AKigelia africana, Ram-Ramipril 
Table 3 Effects of Kigeliaafricanaleaf extract on serum lipid profile of normotensive

\begin{tabular}{|l|l|l|l|l|l|l|}
\hline Group & CHOL(mg/dl) & TG(mg/dl) & HDL(mg/dl) & LDL(mg/dl) & VLDL(mg/dl) & CRL \\
\hline Control & $29.22 \pm 0.91^{\mathrm{d}}$ & $21.67 \pm 0.21^{\mathrm{e}}$ & $15.26 \pm 1.23^{\mathrm{a}}$ & $9.63 \pm 0.82^{\mathrm{d}}$ & $4.33 \pm 0.04^{\mathrm{e}}$ & $1.92 \pm 0.11^{\mathrm{d}}$ \\
\hline K.A(25mg/kg) & $25.89 \pm 0.52^{\mathrm{b}}$ & $20.13 \pm 0.39^{\mathrm{d}}$ & $17 . .28 \pm 0.77^{\mathrm{b}}$ & $4.58 \pm 0.61^{\mathrm{b}}$ & $4.03 \pm 0.08^{\mathrm{d}}$ & $1.50 \pm 0.06^{\mathrm{b}}$ \\
\hline K.A(50mg/kg) & $23.19 \pm 1.04^{\mathrm{a}}$ & $17.24 \pm 0.25^{\mathrm{b}}$ & $17.28 \pm 0.60^{\mathrm{b}}$ & $2.46 \pm 1.11^{\mathrm{a}}$ & $3.45 \pm 0.05^{\mathrm{b}}$ & $1.34 \pm 0.07^{\mathrm{a}}$ \\
\hline K.A(100mg/kg) & $25.72 \pm 0.95^{\mathrm{a}}$ & $16.85 \pm 0.17^{\mathrm{a}}$ & $15.93 \pm 0.7^{\mathrm{ab}}$ & $5.79 \pm 0.82^{\mathrm{b}}$ & $3.37 \pm 0.03^{\mathrm{a}}$ & $1.58 \pm 0.08^{\mathrm{b}}$ \\
\hline Ram. (I mg/kg) & $27.32 \pm 0.86^{\mathrm{c}}$ & $19.78 \pm 0.22^{\mathrm{c}}$ & $15.80 \pm 1.6^{\mathrm{ab}}$ & $7.57 \pm 1.51^{\mathrm{c}}$ & $3.96 \pm 0.04^{\mathrm{c}}$ & $1.74 \pm 0.17^{\mathrm{c}}$ \\
\hline
\end{tabular}

Values are expressed as mean \pm standard deviation $(n=5)$. Values with different superscript(s) in a row are significantly different (P<0.05). CHOL-Cholesterol; LDL -Low density lipoprotein; TG-triglyceride; VLDL-Very low density lipoprotein; HDL-High density lipoprotein; CRI- Coronary risk index; K. A-Kigelia africana, Ram-Ramipril

Table 4 Effects of Kigeliaafricanaleaf extract on antioxidant parameters of normotensive albino rats

\begin{tabular}{|l|l|l|l|l|}
\hline Group & $\begin{array}{l}\text { CAT Activity } \\
\text { ( } \boldsymbol{\mu m o l / m i n} / \mathbf{m g}-\end{array}$ & $\begin{array}{l}\text { SOD Activity } \\
\text { protein) }\end{array}$ & $\begin{array}{l}\text { GSH Concentration } \\
\text { protein) }\end{array}$ & $\begin{array}{l}\text { TP (mgprotein/ml } \\
\text { (mmole/min/mg- } \\
\text { protein) }\end{array}$ \\
\hline Control & $3.82 \pm 0.2 \mathrm{~d}$ & $1.77 \pm 0.01 \mathrm{a}$ & $2.28 \pm 0.34 \mathrm{a}$ & $3.75 \pm 0.20 \mathrm{~d}$ \\
\hline K.A $(25 \mathrm{mg} / \mathrm{kg})$ & $2.55 \pm 0.3 \mathrm{~b}$ & $4.15 \pm 0.14 \mathrm{~d}$ & $5.31 \pm 0.39 \mathrm{~d}$ & $1.72 \pm 0.21 \mathrm{ab}$ \\
\hline K.A $(50 \mathrm{mg} / \mathrm{kg})$ & $2.57 \pm 0.45 \mathrm{~b}$ & $3.46 \pm 0.02 \mathrm{~b}$ & $5.10 \pm 0.49 \mathrm{~cd}$ & $1.97 \pm 0.25 \mathrm{~b}$ \\
\hline K.A $(100 \mathrm{mg} / \mathrm{kg})$ & $3.01 \pm 0.18 \mathrm{c}$ & $3.85 \pm 0.18 \mathrm{c}$ & $4.76 \pm 0.36 \mathrm{c}$ & $1.56 \pm 0.24 \mathrm{a}$ \\
\hline Ramipril(1mg/kg) & $2.90 \pm 0.27 \mathrm{bc}$ & $3.37 \pm 0.23 \mathrm{~b}$ & $3.36 \pm 0.14 \mathrm{~b}$ & $2.59 \pm 0.18 \mathrm{c}$ \\
\hline
\end{tabular}

Values are expressed as mean \pm standard deviation $(\mathrm{n}=5)$. Values with different superscript $(\mathrm{s})$ in a row are significantly different $(\mathrm{P}<0.05)$. K. A-Kigelia africana, Ram-Ramipril

\section{Discussion}

In recent years dietary plants with antioxidative property have been the center of focus. It is believed that these plants can prevent or protect tissues against damaging effect of free radicals [22]. Free radicals and ROS have been implicated in a large number of human diseases [23]. The beneficial medicinal effects of plant materials typically result from the combinations of secondary metabolites present in the plant, through additive or synergistic action of several chemical compounds acting at single or multiple target sites associated with a physiological process [24].

Blood pressure is the force of blood pushing against the blood vessel walls. It is determined by the rate of blood flow produced by heart (cardiac output) and the resistance of arterioles to blood flow. Hypertension can lead to damaged organs, as well as several illnesses, such as renal failure (kidney failure), heart failure, stroke or heart attack. Different therapeutic strategies, including plant-derived natural products have been employed to treat and prevent hypertension [25].

The present study revealed the significant hypotensive effect of methanolicleaf extract of Kigeliaafricanaon the arterial blood pressure of normotensive wistar rats. Oral administration of methanolicleaf extract of Kigeliaafricana(25-, 50and $100 \mathrm{mg} / \mathrm{kg}$ ) and reference drug, ramipril $(1 \mathrm{mg} / \mathrm{kg})$ for 14 consecutive days significantly $(\mathrm{P}<0.05)$ decreased the blood pressure (systolic and diastolic), pulse presure, mean arterial blood pressure and heart rate of normotensive albino rats in a dose-dependent manner. The extract showed superior hypotensive activity at doses of $50 \mathrm{mg} / \mathrm{kg}$ and $100 \mathrm{mg} / \mathrm{kg}$ when compared to ramipril at $1 \mathrm{mg} / \mathrm{kg}$ even though it could not be ascertained from the study whether similar mechanisms are involved. The observed reduction of both systolic and diastolic blood pressure inKigeliaafricana $(25,50$ and $100 \mathrm{mg} / \mathrm{kg}$ )-treated rats (Table 5) suggest that Kigeliaafricanaat those dosages might be capable of offering protection against high blood pressure. 
Biomarkers (enzyme) are located in the different cells, tissues and organs in the body system and leak out and make their way into the general circulation when these cells, tissues and organs are damaged [26]. (Seifter and England, 1982). Detection of injury in a cell, tissue or an organ could be afforded by measuring serum levels of known marker enzymes such as aspartate aminotransferase (AST), ALT, ALP and creatine kinase (CK) activity.Several studies have reported elevation in the activities of serum concentration on the normal rats AST and ALT in disease states [26]. This might possibly be due to the release of these enzymes from the cytoplasminto the blood circulation rapidly after rupture of the plasma membrane and cellular damage.

Aspartate aminotransferase (AST) is present in large amount in the heart muscle tissues but is normally found in liver, red blood cells, pancreas and kidney and is among the most sensitive markers employed in the diagnosis of organ damage [27]. (Sallic et al, 1991). Oral administration of the methanolic extracts of Kigelliaafricanaleaf significantly reduced the activities of AST in normal rats (Table 6). This is an indication that the extracts might prevent heart, kidney and liver damage by maintaining the integrity of the plasma membrane and suppressing the leakage of the enzymes through the membrane.The significant $(\mathrm{P}<0.05)$ reduction in serum AST activity by ramipril and Kigeliaafricanaleaf extract treatment may be correlated to their cardioprotective effects.

The serum activity of alkaline phosphatase (ALP) is elevated in a large number of disorder that affects the damage of bile, such as gall stone or tumor blocking the flow of bile in smaller bile channels within the liver [28]. The observation that the serum ALP activityoframiprilandextract-treated rats wasnot elevated might indicate that the extract, at the evaluated dosages, did not induce defect in the liver, bones or kidney whichnormallyhave high activity of the enzyme.

ALT is one of the most commonly used markers of hepatocytes injury, and elevation in serum level is usually observed in cases of hepatotoxicity [29]. Serum ALT activity of animals treated with ramipril and and all dosages of Kigeliaafricanawere not increased, but rather slightly decreased, when compared to the control. This might indicate the safety of the extract to the hepatocytes at the evaluateddosages.A number of scientific reports indicate that certain flavonoids, terpenoids and steroids have protective effect on liver due to their antioxidant properties [30]. Consequently, antioxidant phytochemicals in the the extracts could be responsible for the observed hepatoprotective activity.

Also, the present study revealed that Kigeliaafricanaleaf extract caused significant reduction in serum creatine activity of rats over a 14-day period.The serum activity of this cellular enzyme is directly related to the intactness of the plasma membrane of the cardiac cells. Hence, the inhibition of the release of this enzyme into the serum by the extract could be due to its action in maintaining cardiac membrane integrity thereby restricting the leakage of the enzyme into the serum [31].

Lipids play a vital role in the pathogenesis of oxidative stress. The increased level of serum lipid in oxidative stress represents a risk factor for coronary heart disease [32].

In disease state, the concentration of serumfree fatty acids is elevated as a result of free fatty acids out flows from fat depots where the balance of the free fatty acid esterification triacylglycerol lipolysis cycle is displaced in favour of lipolysis [33].

Thus an excess fatty acid in the plasma promotes the conversion of excess fatty acids into phospholipids and cholesterol in the liver. These two substances along with excess TGs formed in the liver may be discharged in the liver in the form of lipoproteins [34]. HDL is an anti-atherogenic lipoprotein; it transports cholesterol from peripheral tissues into the liver and thereby acts total cholesterol in normal rats as a protective factor against coronary heart disease.

The present study revealed that methanolic extract of Kigeliaafricanaleaf has a profound effect on serum lipid profile of rats. The values obtained showed that ramipril and the extract, at all dosages, caused significant reduction in TC, TG, LDL-C and VLDL and CRI while there was slight increase in the level of HDL when compared to the control. [35], reviewed that a statistically significant association occur between elevated serum total cholesterol and low density lipoprotein cholesterol (LDL-c) and the severity of Retinal hard exudation in patients with diabetic retinopathy. Elevated levels of TG, TC and LDL-c are documented as risk factors for atherogenesis. LDL-c in its oxidized or acetylated form has been identified as a major atherogenic particle; as it not only load macrophages with cholesterol for the formation of foam cells but also because it is chemotactic for circulating monocytes. [36]. The blood level of HDL-c in contrast bears an inverse relationship of the risk of atherosclerosis and coronary heart disease, that is, the higher the level, the smaller the risk [37]; [38]. Going by the aforementioned, the present study showed the beneficial, hypolipidemic effect of the extract. 
Free radical scavenging enzymes like SOD and catalase (CAT) protects the biological system from oxidative stress [39]; [40], and are the best studied cellular antioxidant [40]. Superoxide dismutase, SOD, is a specific antioxidant enzyme which dismutates $0_{2}$-and forms $\mathrm{H}_{2} \mathrm{O}_{2}$ that is eventually scavenged by catalase [41]. These enzymes prevent generation of hydroxyl radicals and protect the cellular constituents from oxidative damage [42]. The significant increase in cardiac SOD activity, observed in ramipril ( $1 \mathrm{mg} / \mathrm{kg}$ ) and Kigeliaafricanaleaf extract (25,50 and $100 \mathrm{mg} / \mathrm{kg})$-treated rats might suggest that the extract at those dosages were capable of boosting the enzyme activity to offer proection against superoxide anions radicals.

The perixosomal, catalase enzyme catalyzes the decomposition of hydrogen peroxide to less reactive gaseous oxygen and water molecules [43]. Hydrogen peroxide is a harmful by- product of many metabolic processes, and to prevent damage, it must be quickly converted into other, less dangerous substances. Significant decrease in cardiac catalase activity was observed in animals subjected toramipril (1mg/kg b.w.) and Kigeliaafricana(25- 50- and 100mg/kg).The decrease in the activity of CAT in the present study could be attributed to the excessive utilization of the enzyme in attenuating the reactive oxygen species $\left(\mathrm{H}_{2} \mathrm{O}_{2}\right)$ arising from SOD actions [44].

The endogenous antioxidant molecule, (GSH), can interact directly with certain ROS (like hydroxyl radicals) to detoxify them, as well as performing other critical activities in the cell [45]. The GSH level, which comprises in most instances the bulk of cellular non-protein sulfhydryl groups, is a measure of cellular redox status [45], and usually depleted during oxidative stress conditions. GSH is also an essential component of the glutathione peroxidase system where the selenium containing microsomal enzyme, GPx, catalyses the degradation of hydrogen peroxide to water and reduces the organic peroxides to alcohols, providing another route for eliminating toxic oxidants [45]. The observed increase in GSH level in the serum of treated rats lent support to the protective antioxidant benefits of the intervention.

\section{Conclusion}

The results in the present study revealed the antioxidant activity of Kigeliaafricanaleaf extract in vitro and its nontoxicity to the heart and extra cardiac tissues of rats at the evaluated dosages (25-, 50- and 100mg/kg). The results further support the hypolipidemic and hypotensive of Kigeliaafricanaleaf extract, thereby lending credence to the ethnomedicinal use of the leaf in the management of heart-related diseases. The study plant could thus serve as source of useful hypolipidemic and hypotensive agents.

\section{Recommendation}

Further studies could be carried out to ascertain the effect of prolonged treatment with the plantextract in order to ascertain its chronic effect on the organs of rats. Also, characterization of the active phytochemicals responsible for the observed hypolipidemic and hypotensive effect of the leaf, and their individual contributions, might be necessary

\section{Compliance with ethical standards}

\section{Acknowledgments}

This work was supported by Centre for Research and Innovation Development, The Federal Polytechnic, Ado Ekiti. The authors are also grateful to the students of the Biochemistry Unit, Department of Science Technology, The Federal Polytechnic, Ado Ekiti.

\section{Disclosure of conflict of interest}

All authors declare that no conflict of interest in this work.

\section{Statement of ethical approval}

All authors hereby declare that the research has been determined exempt from review by the Polytechnic animal research and ethics review committee and that the principles of the laboratory animal care were followed.

\section{References}

[1] Akinmoladun AC, Ibukun EO, Afor E, Akinrinlola BL, Onibon TR, Akinboboye AO, Obuotor EM,Farombi EO. Chemical constituents and antioxidant activity of Alstonia boonei.Afr. J.Biotechnol. 2007; 6(10): 1197-1201. 
[2] Rice-Evans CA, Miller NJ, Paganga G. Structure-antioxidant activity relationships of flavonoids and phenolic acids.Free Radic Biol Med. 1996;20(7):933-956.

[3] Oboh G, Rocha JBT. Polyphenols in red pepper [Capsicum annuum var. aviculare (Tepin)] and their protective effect on somePro-oxidants induced lipid peroxidation in brain and liver- In vitro. Eur.Food Res. Technol. 2007; 225: 2 .

[4] Farombi E0, Nwankwo JO, Emerole GO. Effect of methanolic extract of browned yam flour diet on 7,12Dimetylbenzanthracene (DMBA) and 3-methylcholanthrene (3-MC) induced. 1998.

[5] Halliwell B,Gutteridge JMC. Free Radicals in Biology and Medicine, Oxford Press, Oxford, UK. 1999.

[6] Marchesi C, Paradis P, Schiffrin EL; Paradis; Schiffrin " Role of the rennin-angiotensin system in vascular inflammation" Trends pharmacol. Sci. 2008; 29(7): 367-74.

[7] Jackson SJ, Houghton PJ, Photiou A,Retsas S. the isolation of of a novel of antineoplastic compounds from a bioassay guided fractionation stem bark of Kigelia pinnata British Journal of cancer. 1996; 73.

[8] Adeboye JO, Fajonyomi MO, Makinde JM,Taiwo OB. A preliminary study on the hypotensive activity of Persea americana leaf extracts in anaesthetized normotensive rats. Fitoterapia. 1999; 70: 15-20.

[9] Mattenheimer, H. (1981). CK-MB Methods and clinical significance, Proceedings of the CK-MB symposium; 5157.

[10] Stein, W. (1981).CK-MB Methods and clinical significance, Proceedings of the CK-MB symposium; 61-74.

[11] Reitman S, Frankel S, Amer J Clin. Path. 1957; 28:56.

[12] Englehardt A. Et al., Aerztl Labor. 19701642.

[13] Trinder P. Determination of glucose in blood usingglucise oxidase with an alternative oxygen acceptor. Annals of Clinical Biochemistry. 1969; 6: 24-27.

[14] Tietz, N.W. (1990). Clinical Guide to Laboratory Tests.Second Edition W.B. Saunders Company, Philadelphia, USA 554- 556.

[15] Grove, T.H. (1979). Effects of reagent $\mathrm{pH}$ on the determination of high density lipoprotein cholesterol by precipitation with sodium phosphotungstate-magnesium.Clinical Chemistry.25: 560-564.

[16] Friedwald WT, Levy RI,Fredrickson DS. Estimation of the concentration of low density lipoprotein cholesterol in the plasma, without the use of preparative ultracentrifuge.Clinical Chemistry. 1972; 18: 499-502.

[17] Sinha AK. Colorimetric assay of catalase.Journal of Analytical Biochemistry. 1972; 47: 389 -394.

[18] Misra, H. P., and Fridovich I. (1972): Journal of Biological Chemistry. ASBMB.

[19] Beutler E, Duran 0,Kelly MB. Improved method for the determination of blood glutathione.Journal of Laboratory Clinical Medcine. 1963; 61: 882-890

[20] Weichselbaum RR,Hellman S. Oligometastase.Journal of Clinical Biochemistry. 1995; 13: 8-10.

[21] Anthony H, Richard A. Post Hoc Anova Statistics for Biologists. Microbiologist. 2006; 6: 34-36.

[22] Osawa T, Kato Y. Protective role of antioxidative food factors in oxidative stress caused by hyperglycemia. Ann. NY. Acad. Sci. 2005; 1043: 440-451.

[23] Wegener T, Fintelmann V. Flavonoids and bioactivity. Wein Med Wochem Schr 1999; 149:241-247.

[24] Briskin DP. Medicinal plants and phytomedicines - linking plant biochemistry and physiology to human health. Plant Physiology. 2000; 124: 507-514.

[25] Kirsch JF, Eichele G, Ford G, Vincent MG, Jansonius JN, Gehring H et al. "Mechanism of action of aspartate aminotransferase proposed on the basis of its spatial structure". J Mol Biol. 1984; 174 (3): 497-525.

[26] Seifter S,S England. Energy Metabolism, In: Arias I, Popper H, Schacter D. (Eds.) The Liver: Biology and Pathology, New York Raven Press. 1992; 219-249.

[27] Sallic R, Tredger JM, William R. Drugs and the liver, Biopharmaceutical Drugs Dispos. 1991; 12:251-259.

[28] Grant G. H (1987). Amino acids and proteins; fundamentals of clinical chemistry. Tietz N.W. editor, third Edition, W. B Saunders company Philadelphia USA pg 382-329, 1987 
[29] Singh VK, Dixit P, Sixena PN. Cybil induced hepato biochemical changes in wistar rats. J. Environ Biol 2005; 2(4): 725-727.

[30] Shirwaikar A, K Rajendran, CD Kumar R Bodla. Antidiabetic activity of aqueous leaf extract of Annona squamosa in streptozotocin nicotinamide type 2 diabetic rats. Journal of Ethnopharmacology. 2004; 91: 171-175.

[31] Chen YF, Kobayashi S,Chen J. Short term triiodo-l-thyronine treatment inhibits cardiac myocyte apoptosis in border area after myocardial infarction in rats. Journal of Molecular and Celluar Cardiology. 2008; 44(1): 180187.

[32] Nutrient Data Laboratory, 2010. USDA National Nutrient Database for Standard Reference, Release 23. Retrieved 2011 from http:// www.ars.usd.gov/ ba/ bhnr/nd.

[33] Bopama KN, J Kanna, G Sushma, R Balaraman,SP Rathod. Antidiabetic and antihyperlipidemic effects of neem seed kernel streptozotocinpowder on alloxan diabetic rabbits. Indian Journal of Pharmacology. 1997; 29: 162167

[34] Owolabi OJ, FC Amaechina,M Okoro. Effect of ethanol leaf extract of Newbouldia laevis on blood glucose levels of diabetic rats. Tropical Journal of Pharmaceutical Research. 2011; 10(3): 249-254.

[35] Yeo KT,Su DHW. Diabetic Retinopathy and Serum Lipids.Singapore Med J. 2000; 41(6): 295-297.

[36] Abubakar A, Mabruok MA, Gerie AB, Dikko AA, Aliyu S, Yusuf T, Magaji RA, Kabir MA,Adama UW. Relation of Body Mass Index with Lipid Profile and Blood Pressure in Healthy Female of lower Socioeconomic Group, in Kaduna Northern Nigeria.Asian Journal of Medical Sciences. 2009; 1(3): 94-96.

[37] Witztum JL,Stemberg D. Role of oxidized low density lipoprotein in atherogenesis. J. Clin. Invest. 1991; 88: 17851792.

[38] Palinski, W., Rosenfeld, M. and Yla-Hertuala, S. (1989). Low density lipoprotein undergoes oxidative modification in vivo., Proc. Natl. Acad. Sci., USA. 86: 1372-1376.

[39] Houghton P. The sausage tree (Kigelia pinnata).Journal of Ethnobotany and Recent Scientific Work. 2002; 68(1): 14-20.

[40] Jeremy M, JL Tymoczko,L Stryer. Biochemistry, 5th Edition. Freeman, W.H. and Company, N.Y.2002; $306-311$.

[41] Irmak MK, Fadillioglu E, Gulec M, Erdogan H, Yagmurca M, Akyoi O. Effects of electromagnetic radiation from a cellular telephone on the oxidant and the antioxidant levels in rabbits.Cell.Biochem.Funct. 2002; 20: 279-283.

[42] Scott MD, Lubin BH, Kuypers FA. Erythrocytes defence against hydrogen peroxide. Preminient importance of catalase. J. Lab. Chin. Med. 1991; 118:7-16.

[43] Gaetani GF, Ferraris AM, Rolfo M, Mangerini R, Arena S, Kirkman HN."Predominant role of catalase in the disposal of hydrogen peroxide within human erythrocytes".Blood. 1996; 87(4): 1595- 9.

[44] Levine M, S Rumsey, Y Wang, J Park, R Daruwala.Vitamin C".In Stipanuk MH. Biochemical and physiological aspects of human nutrition. 2000; 5(6): 541-67.

[45] Chance B, Sies H,Boveris A. Hydroperoxide metabolism in mammalian organs.Physiol. Res. 1989; 59: 527-605. 